\title{
The Anti-Cancer Property of Mumie as Natural Product on Human Cervical Cancer Cell Line (HeLa)
}

\author{
Azin Tavassoli, Malihezaman Monsefi \\ Biology Department, College of Sciences, Shiraz University, Shiraz, Iran \\ Accepted: 25/10/2020 \\ Published: 20/06/2021
}

Received: 15/08/2020

\begin{abstract}
Mumie is a natural component found in some mountains, such as the Himalayas, as well as in some mountainous of Iran. It contains of humic and phenolic compounds that have antioxidant and anti-cancer properties. Therefore, in this study, anti-cancer and antioxidant properties of mumie were examined on Human Cervical Cancer Cell Line (HeLa). HeLa cells and normal fibroblasts (NIH) were cultured in DMEM/F12 with mumie at concentrations of $0,100,200,300,400,500$ and $1000 \mu \mathrm{g} / \mathrm{ml}$ for 24 and $48 \mathrm{~h}$. The bioviability of these cells were evaluated using MTT assay. Chromatin condensation and apoptosis of these cells were examined using acridine orange and aniline blue staining respectively. Antioxidant property of mumie on NIH cells was evaluated by $10 \mathrm{mM} \mathrm{H}_{2} \mathrm{O}_{2}$ and neutral red test. MTT assay revealed bioviability of HeLa cells decreased but chromatin condensation increased in concentration of $100 \mu \mathrm{g} / \mathrm{ml} \mathrm{mumie}$ treated culture. Apoptosis of the HeLa cells were observed in $100 \mu \mathrm{g} / \mathrm{ml}$ mumie treated culture. Mumie did not affect the bioviability, chromatin condensation and apoptosis of NIH cells but 500 and $1000 \mu \mathrm{g} / \mathrm{ml}$ concentrations were toxic and induced cell death. The cell cultures in different concentrations of mumie after $24 \mathrm{and} 48 \mathrm{~h}$ showed the similar results. NIH cells bioviability increased in $500 \mathrm{and} 1000 \mu \mathrm{g} / \mathrm{ml}$ concentrations of co-culture of $\mathrm{H}_{2} \mathrm{O}_{2}$ and mumie that confirmed the antioxidant property. It concluded that even low concentrations of mumie could destroy HeLa cells without any side effect on normal cells. Therefore, it can be used for cervical cancer treatment but further research is needed.
\end{abstract}

Keywords: Apoptosis, Cervical cancer, Mumie

\section{Introduction}

Cancer burden rise to 18.1 million infection and 9.6 million deaths worldwide in 2018 (1). Common cancer treatments such as chemotherapy, radiation therapy, and hormone therapy have numerous side effects. Some typical side effects of chemotherapy are vomiting, constipation or diarrhea and hair loss (2). In recent years, increasing the new cases of cervical cancer among all types of cancer has become a major medical concern. However, the treatment of intermittent cervical cancer disease remains ineffectual to a great extent (3). Consequently, researchers are attempting to find more effective remedies to cure this type of cancer. One of the approaches that has been taken into consideration of numerous scientists today, is the utilization of natural compounds like herbs. The use of herbs in disease treatment has existed for thousands of years in many parts of the world. Plants are one of the most important natural sources for cancer treatment because many of them are capable to inducing apoptosis pathway and blocked in cancer cells (4).

Approximately, $50 \%$ of the modern anticancer drugs have been originated from the natural products. Therefore, the use of natural products in the development of new drugs has been a great interest for researchers. For the cancer treatment, Traditional Chinese Medicine has been used natural products as adjuvant therapy in conjunction with chemotherapy and radiotherapy for inhibiting the toxic effects of the treatments, as well as improving overall efficacy $(5,6)$. Mumie is one of the natural substances that individuals have utilized as a healing compound for a long time. It is a brownish, rocky exudate found in some mountainous areas. The chemical content of the mumie is mostly originated from organic humic substances and plants (7). Other mumie components include phenolic compounds and some minerals such as fatty acids, albumin, sterols, amino acids, 3,4 benzocoumarin, aromatic carboxylic acids and polyphenols. The efficacy of mumie has been proven for treating diseases such as anemia, diabetes, high cholesterol, joint and bone disorders, and chronic pain (8). Also, it mainly used to treat people with weakness, inflammation, bone fracture, bleeding and wound healing (9). Based on (10) administration of $200-600 \mathrm{mg} /$ dose of shilajit in mice results in morphological and phagocytotic changes in peritoneal macrophages. (11) showed that shilajit can diminish gastric ulcer record by increasing mucus barrier. They also proved that shilajit has anti-inflammatory effect in carrageenan-induced acute pedal edema, granuloma pouch and adjuvant-induced arthritis in rats.

There are many researches for healing effects of mumie in bone fracture. Also, some researcher has been reported anti-cancer property of mumie but we did not found its effect on cervical cancer. Considering the potency of mumie in curing all above mentioned medical complications, the aim of the present study was to investigate the anti-cancer properties of mumie on human cervical cancer cells (HeLa).

Correspondence author: Monsefi Malihezaman, Prof. of Anatomy, Biology Department, College of Sciences, Shiraz University Shiraz-Iran. Tel: 0098-713-3167357, Fax: 0098-713-2280916, Email address: monsefi.g@gmail.com and monsefi@susc.ac.ir. 


\section{Materials and methods \\ 1.2 Extract preparation}

Black mumie were purchased from a commercial source in Kerman, Iran. Mumie were powdered and $0.01 \mathrm{~g}$ were solved in $12.5 \mathrm{ml}$ culture media in a water bath for $10 \mathrm{~min}$. Mumie extract were vortexed for 10 minutes and sterilized with 0.45 $\mu \mathrm{m}$ syringe filter. The concentrations of 50, 100. 150, 200, 250, $300,400,500,1000,2000$ and $3000 \mu \mathrm{g} / \mathrm{ml}$ were prepared. After pilot study, the concentrations of 100. 200, 300, 400, 500 and $1000 \mu \mathrm{g} / \mathrm{ml}$ were selected.

\subsection{Cell culture}

The effects of mumie on the human cervical cancer cell line (HeLa) were evaluated. A NIH cell line from the fibroblast of Swiss albino mouse embryo tissue as a normal cell was cultured with the same method to compare with the cancer cell line. These cells were cultured in DMEM/F12 (Dulbecco's Modified Eagle Medium, Gibco, USA) containing $10 \%$ fetal bovine serum (FBS, Gibco, USA) and 5\% Penicillin/Streptomycin (Gibco, USA). The cells were incubated at $37^{\circ} \mathrm{C}$ and $5 \% \mathrm{CO}_{2}$. The media were changed every 2 days. After 80-90\% confluency on the flask, the cells were passaged using Trypsin $0.25 \%$ (Bio-IDEA Iran).

Cells number and viability were estimated using a haemocytometer under a light microscope after vital staining with trypan blue (Sigma-Aldrich, USA). Number of $1 \times 10^{4}$ cells were grown and maintained in $100 \mu \mathrm{l}$ per each well of 96 well plate and $5 \times 10^{5}$ cells in $200 \mu \mathrm{l}$ per each well of 24 well plate. All cells were incubated at $37^{\circ} \mathrm{C}$ with $5 \% \mathrm{CO}_{2}$ for 24 and $48 \mathrm{~h}$. Each concentration was repeated in 3 wells of well plate and in three well plates separately.

\subsection{MTT assay}

To evaluate the cytotoxicity effects of mumie on the HeLa cells, MTT colorimetric assay was applied. Briefly, $1 \times 10^{4}$ cells/well were transferred into 96-well culture plates containing $100 \mu \mathrm{l}$ of DMEM/F12 and incubated for $24 \mathrm{~h}$. NIH cell line was cultured with the same method to compare with the cancer cell lines. The culture medium was replaced by fresh medium containing mumie extract at concentration of 100.200, $300,400,500$ and $1000 \mu \mathrm{g} / \mathrm{ml}$ after $24 \mathrm{~h}$ and incubated for 24 and $48 \mathrm{~h}$. MTT solution was prepared at $1 \mathrm{mg} / \mathrm{ml}$ in PBS and was filtered through a $0.2 \mu \mathrm{m}$ syringe filter. Then MTT solution at 1:10 of total volume was added into each well. Cells were incubated for 4 hours at $37^{\circ} \mathrm{C}$ with $5 \% \mathrm{CO}_{2}$ and complete humidity. After 4 hours, the MTT solution was removed and replaced with $200 \mu \mathrm{l}$ of DMSO. The plate was further incubated for 2 hours at room temperature, and the optical density (OD) of the wells was determined using a plate reader at a test wavelength of 570 and $690 \mathrm{~nm}$. Percent of the cell viability was calculated using the equation: (mean OD of treated cells/mean OD of control cells) $\times 100$.

\subsection{Chromatin condensation assay}

The number of $5 \times 10^{5}$ cells were cultured in each well of 24 well plate and then were treated with different doses of mumie for 24 and $48 \mathrm{~h}$. HeLa and NIH cells were fixed in 3\% glutaraldehyde in PBS $0.2 \mathrm{M} 30$ min then stained with $5 \%$ aniline blue (Acros Organics, USA) in 4\% acetic acid $10 \mathrm{~min}$ at $\mathrm{pH}=3.5$. Each well was examined by invert microscope and their photographs were taken by digital camera (Nikon, Japan). Condensed chromatin was stained as dark blue. Intensity of reactions of 100 nuclei in each concentration of each well were scored based on the percentage of cells nuclei color. In this method score 1 to 4 represents light blue nuclei or normal cells, semi-dense nuclei, dens nuclei and dark blue nuclei or compressed cells respectively.

\subsection{Acridine orange/Ethidium bromide (AO/EB) staining}

$\mathrm{AO} / \mathrm{EB}$ staining is used for evaluation of nuclear morphology in apoptotic cells. The number of $5 \times 10^{5}$ cells were cultured in each well of 24 well plate and then were treated with different doses of mumie for 24 and $48 \mathrm{~h}$. After the treatment period, HeLa and NIH cells were harvested and rinsed with PBS. The pellets were resuspended in $\mathrm{AO} / \mathrm{EB}$ solution including $5 \mu \mathrm{l}$ of $\mathrm{AO}$ (Merck, Germany) and $5 \mu \mathrm{l}$ of EB (SinaClon, Iran). After $10 \mathrm{~min}$, the cells were observed using a fluorescence microscope (Nikon Eclipse-E600) and photographs were taken at $\times 100$ magnification using a digital camera (Nikon, Japan). Acridine orange is a vital dye and stains both live and dead cells. Ethidium bromide stains only cells that have lost membrane integrity. Live cells will appear uniformly green. Early apoptotic cells stain green and contain bright green dots in the nuclei as a consequence of chromatin condensation and nuclear fragmentation. Late apoptotic cells also incorporate ethidium bromide and therefore stain orange, but, in contrast to necrotic cells, the late apoptotic cells show condensed and often fragmented nuclei. Necrotic cells stain orange, but have a nuclear morphology resembling that of viable cells, with no condensed chromatin. The nuclei of 100 cells in each concentration of each well were scored based on the percentage of cells nuclei color as normal cells, early apoptotic cells and apoptotic cells.

\section{$6.2 \mathrm{H}_{2} \mathrm{O}_{2}$ assay and Neutral red staining}

To investigate the antioxidant properties of mumie, $\mathrm{H}_{2} \mathrm{O}_{2}$ was added to various concentrations of mumie. $\mathrm{H}_{2} \mathrm{O}_{2}$ causes cell death by oxidation stress and DNA damage. Antioxidant substances were reduced $\mathrm{H}_{2} \mathrm{O}_{2}$ activity in the cells. The number of $5 \times 10^{5}$ cells were cultured in each well of 24 well plate and then were treated with different doses of mumie for 24 and 48 h. Negative control wells contained culture media and in positive control wells $\mathrm{H}_{2} \mathrm{O}_{2}$ were added to culture media. Neutral red staining was then performed to examine living and dead cells. Neutral red is a vital dye that across the mitochondria of living cells but cannot enter in the mitochondria of dead cells. The number of $5 \times 10^{5} \mathrm{NIH}$ cells were cultured in each well of 24 well plate and then were treated with different doses of mumie for 24 and $48 \mathrm{~h} .150 \mu \mathrm{l}$ of neutral red dye was added to each well then fixed for $1 \mathrm{~min}$ by formal calcium. $200 \mu \mathrm{l}$ of acid alcohol (3\% hydrochloric acid in $95 \%$ ethanol) was added to each well for $2 \mathrm{~h}$. Finally, the supernatants were transferred to the new plate and the light absorbance was measured at a wavelength of 540 $\mathrm{nm}$ by a microplate reader. Normal cells revealed higher color intensity than to dead cells.

\subsection{Statistical analysis}

The data were analyzed with One-Way ANOVA using SPSS version 17.5. The $p<0.05$ were considered as significant level. The Tukey post hoc test was used to obtain mean and standard deviation for each parameter and the graphs were plotted using EXCLE software.

\section{Results}

The human cervical cancer cell line (HeLa) of mumie treated cultures showed a significant reduction in cell viability in a concentration and time dependent manner. 

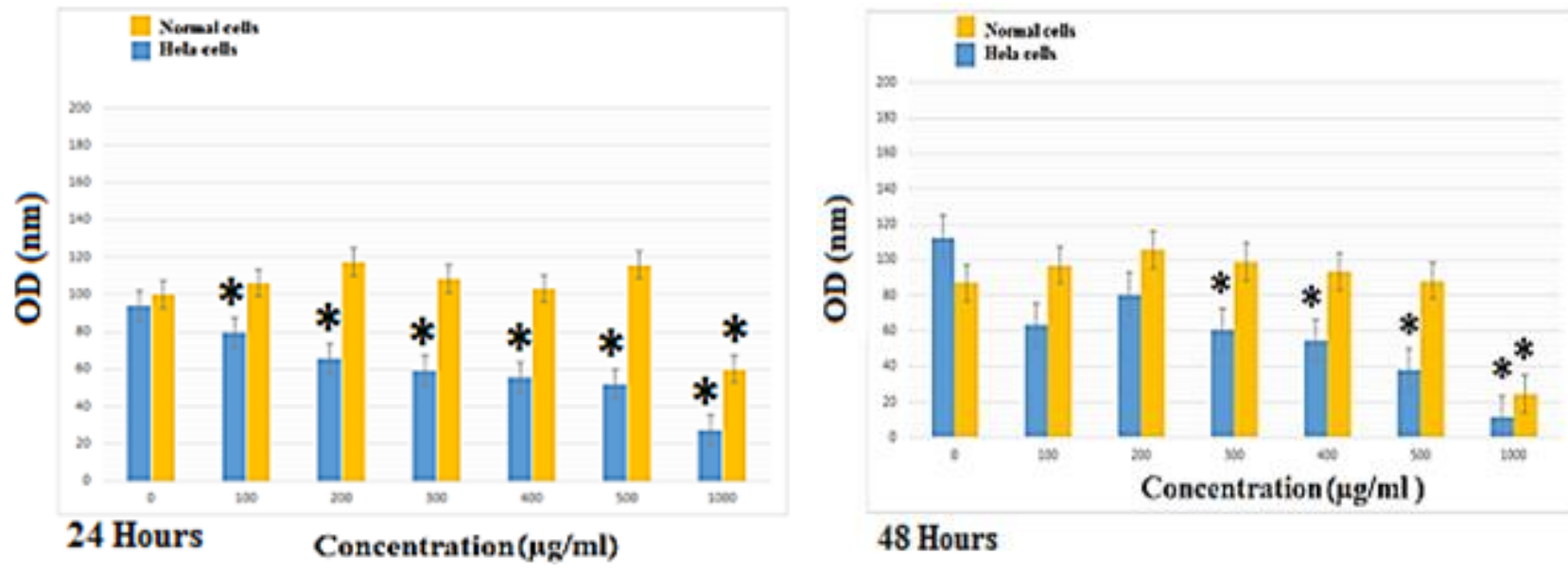

Figure 1: The bio-viability effects of mumie on HeLa and NIH cells cultures at different concentrations after 24 and $48 \mathrm{~h}$ using MTT assay. $*$ Signi ficant difference $(\mathrm{P}<0.05)$ compared to the control culture
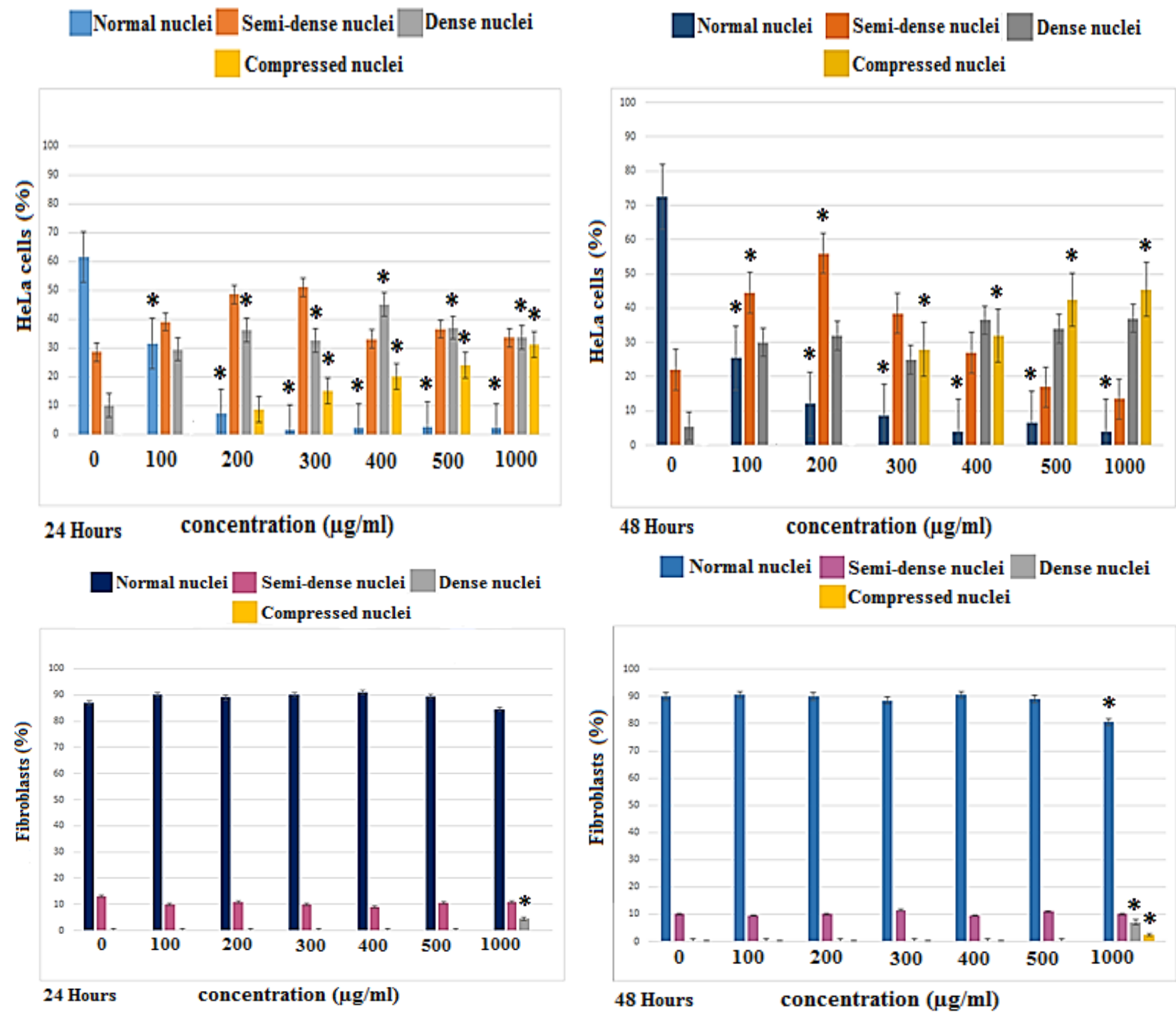

Figure 2: Chromatin condensation of HeLa and NIH cells at different concentrations of mumie treated culture after 24 and $48 \mathrm{~h}$ *Significant difference $(\mathrm{P}<0.05)$ compared to the control culture

The viability of Hela cells reduced from $100 \mu \mathrm{g} / \mathrm{ml}$ concentration significantly $(\mathrm{P}<0.05)$. IC 50 of HeLa cells after $24 \mathrm{~h}$ of mumie treatment were 379.8 , whereas after $48 \mathrm{~h}$ these cells viability decreased at $300 \mu \mathrm{g} / \mathrm{ml}$ concentration. $\mathrm{IC}_{50}$ of $\mathrm{HeLa}$ cells after $48 \mathrm{~h}$ of mumie treatment were $310.4 \mu \mathrm{g} / \mathrm{ml}$. NIH cells had an IC50 of 998.8 and $807.8 \mu \mathrm{g} / \mathrm{ml}$ after $24 \mathrm{~h}$ and 
$48 \mathrm{~h}$ cultures respectively. The results confirmed the sever cytotoxic effect of mumie on cervical cancer c:ell lines (Fig. 1). The aniline blue staining revealed the round and euchromatin nuclei of the HeLa cells in the control culture changed to the condensed and dark chromatin in the different concentrations of mumie treated cultures. Chromatin condensation appears in $100 \mu \mathrm{g} / \mathrm{ml}$ of mumie concentration and nuclei compression saw at $300 \mu \mathrm{g} / \mathrm{ml}$ of mumie concentration treated culture (Fig 2). Higher HeLa cells of the control culture (almost 80\%) showed dark green nuclei and spindle like cytoplasm using AO/EB staining (Figure 5A). HeLa cells in low concentration (100 $\mu \mathrm{g} / \mathrm{ml}$ ) of mumie treated culture showed the early apoptotic changes such as light green nuclei and round and compressed cytoplasm (Fig. 5B). The population of early pre-apoptotic cells increased in $200 \mu \mathrm{g} / \mathrm{ml}$ and higher concentration of mumie treated culture (Fig. 4). The apoptotic changes such yellowish nuclei and well condensed and small cytoplasm saw in 300 $\mu \mathrm{g} / \mathrm{ml}$ and higher concentration of mumie treated culture. In $400 \mu \mathrm{g} / \mathrm{ml}$ concentration of mumie treated culture near $40 \%$ cells showed apoptotic appearance. HeLa cells of $1000 \mu \mathrm{g} / \mathrm{ml}$ concentration of mumie treatment showed yellow to orange color that referred to their apoptosis (Fig 5D). The results of apoptosis of HeLa cells of mumie treated cultures after $48 \mathrm{~h}$ were similar to it in $24 \mathrm{~h}$ culture (Fig. 4 and 5E-H). NIH cells mumie treated cultures after $24 \mathrm{~h}$ did not show any apoptotic changes except in the highest concentration of $1000 \mu \mathrm{g} / \mathrm{ml}$ (Fig. 4) but after $48 \mathrm{~h}$ they revealed some early apoptotic changes in $200 \mu \mathrm{g} / \mathrm{ml}$ concentration of mumie treatment (Fig. 4) but the more than $80 \%$ of NIH cells were normal (Fig. 4 and 5I-L).
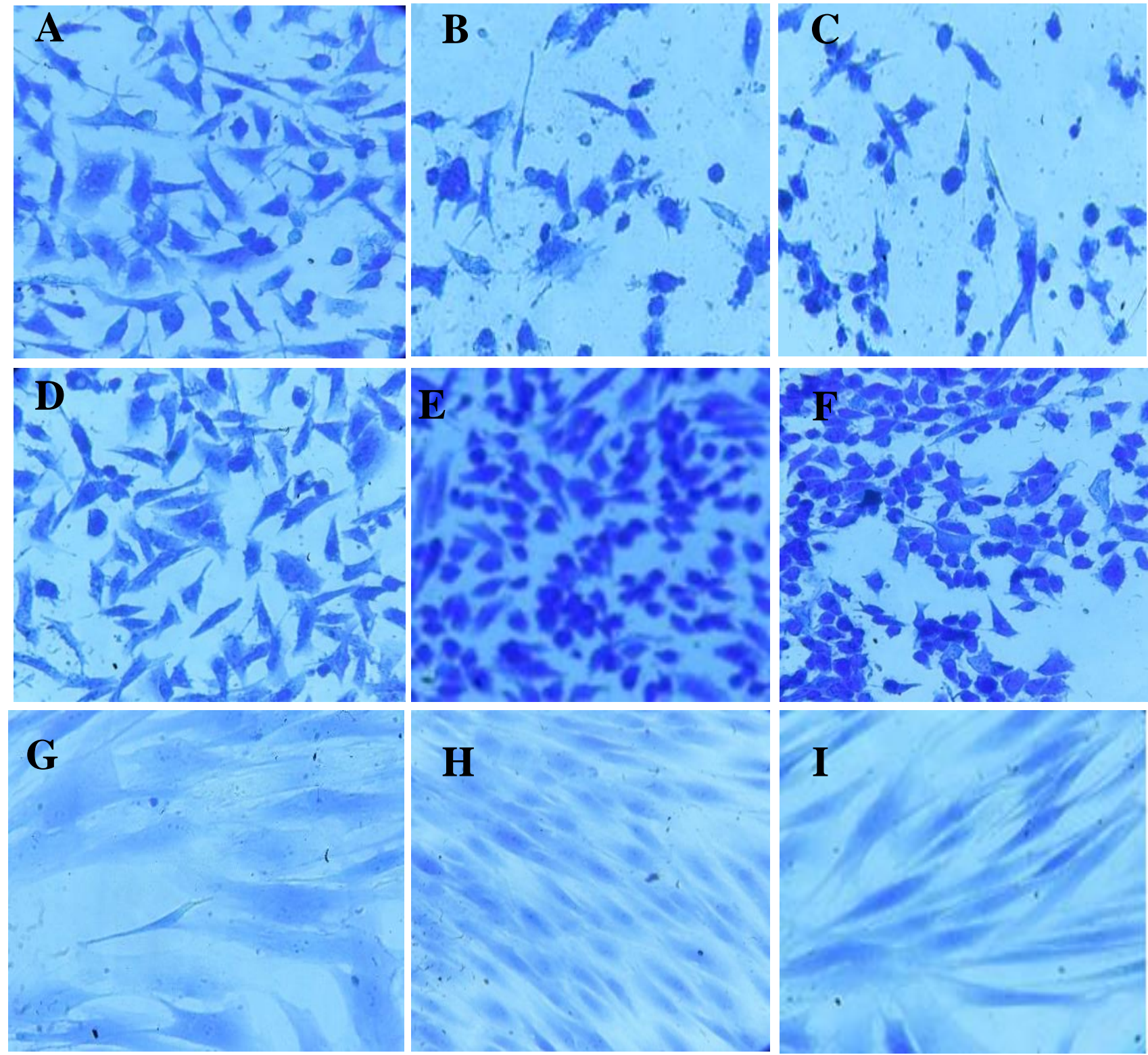

Figure 3- The effects of mumie on HeLa and NIH cells cultures at different concentrations of control, $300 \mathrm{and} 1000 \mu \mathrm{g} / \mathrm{ml}$ respectively. (A-C) showed HeLa cells cultured after 24 h, (D-F) showed HeLa cell cultures after 48 h. (G and H) showed NIH cell cultures after $24 \mathrm{~h}$ and (I) after $48 \mathrm{~h}$. Aniline blue staining. 

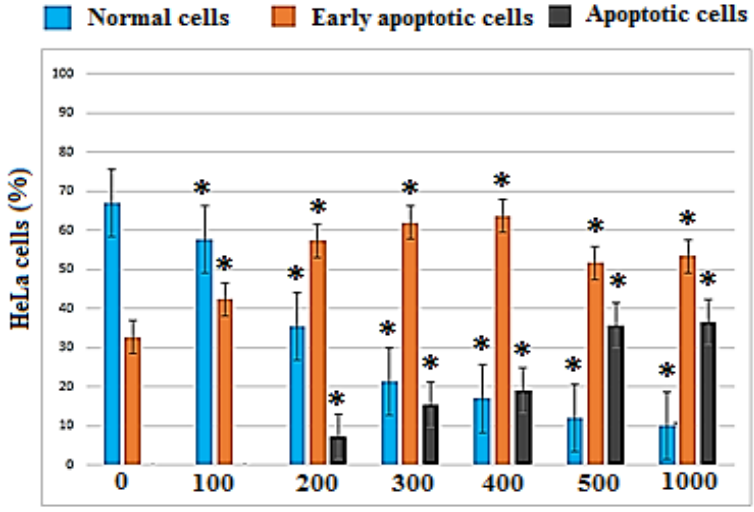

24 Hours concentration $(\mu \mathrm{g} / \mathrm{ml})$

$\square$ Normal cells $\square$ Early apoptotic cells $\square$ Apoptotic cells

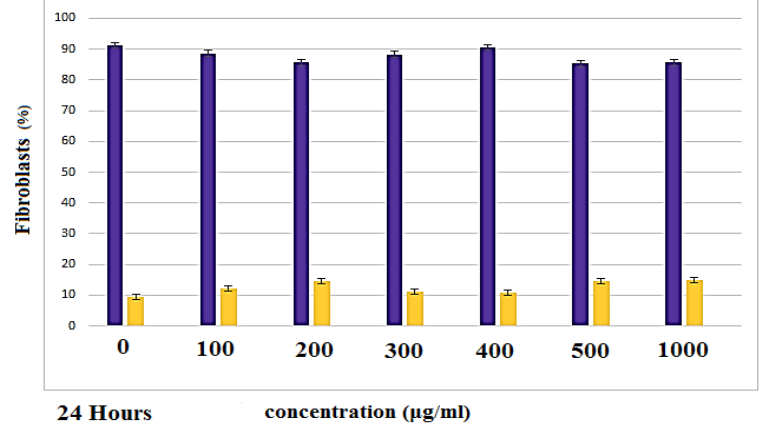

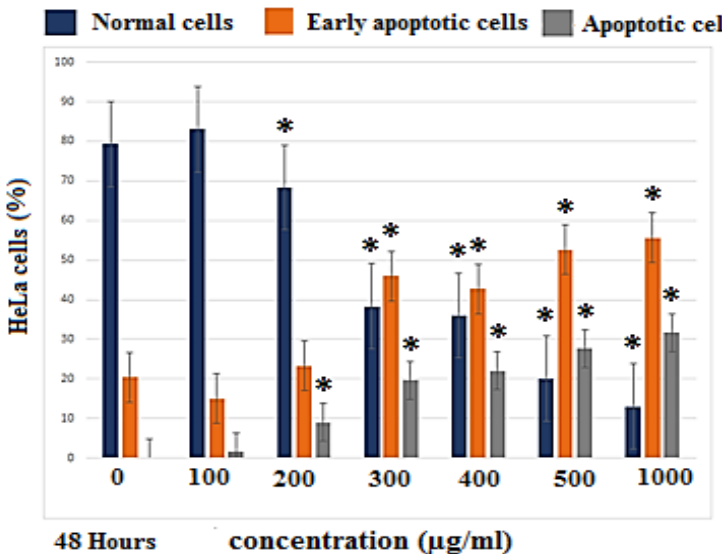

$\square$ Normal cells $\square$ Early apoptotic cells $\square$ Apoptotic cells

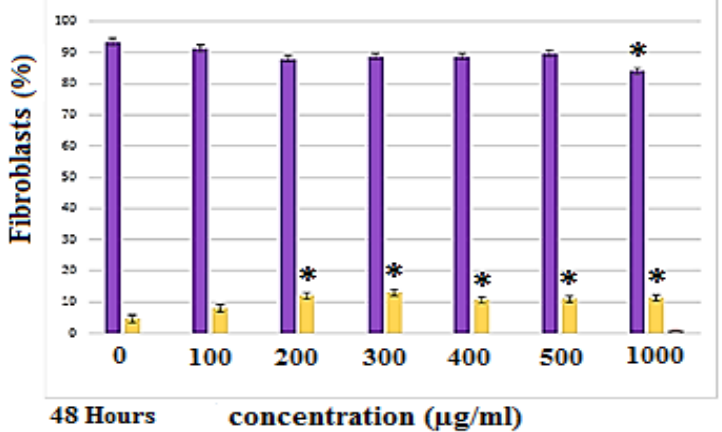

Figure 4: apoptosis of HeLa and NIH cells at different concentrations of mumei treated culture after 24 and 48 h.*Significant difference (P<0.05) compared to the control culture
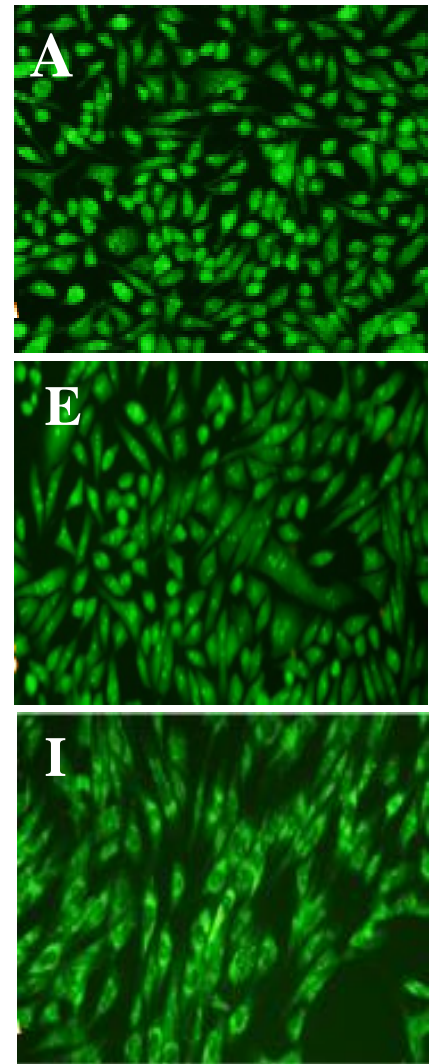
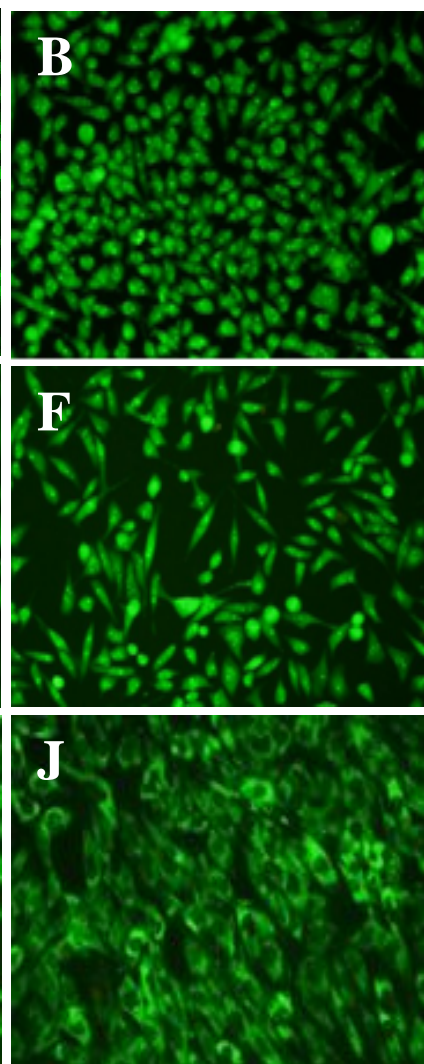
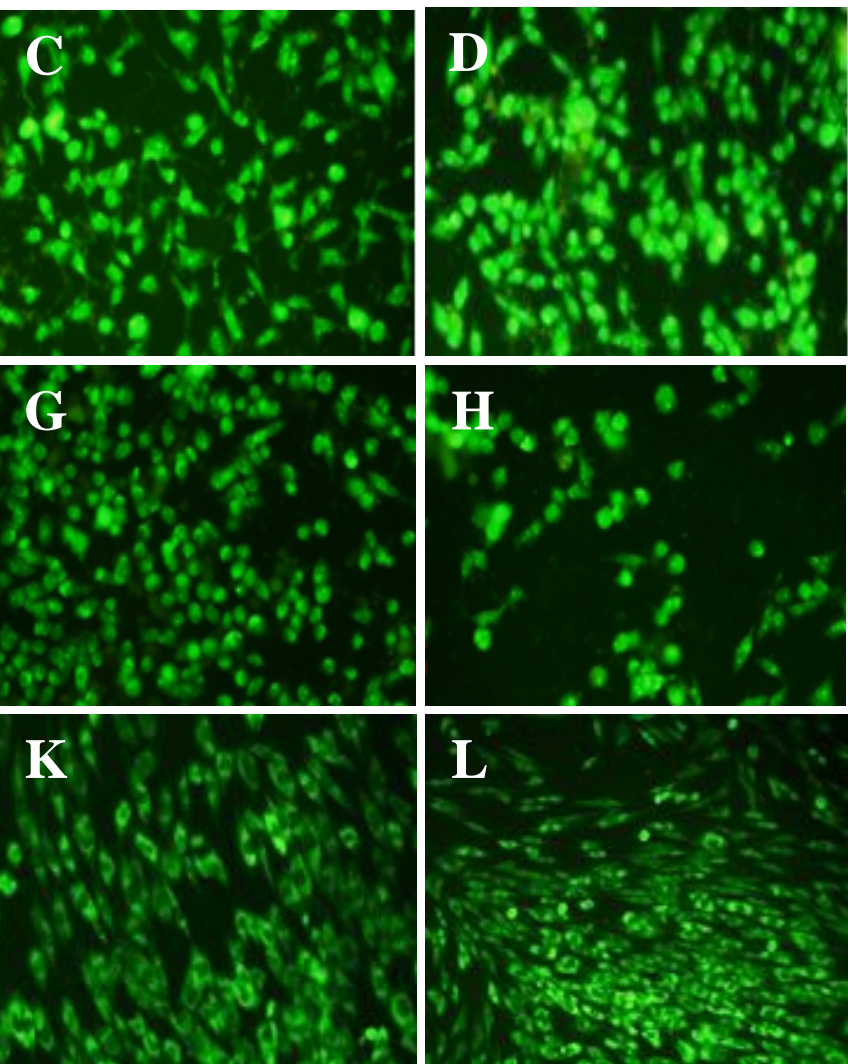

Figure 5: The effects of mumei on HeLa and NIH cells cultures at different concentrations of control, 200, 400 and 1000 $\mu \mathrm{g} / \mathrm{ml}$ respectively. (A-D) showed HeLa cells cultured after 24 h, (E-H) showed HeLa cell cultures after 48 h. (I-K) showed NIH cell cultures after 24 h and (L) after 48 h. Acridine orang/Ethidium bromide staining. 


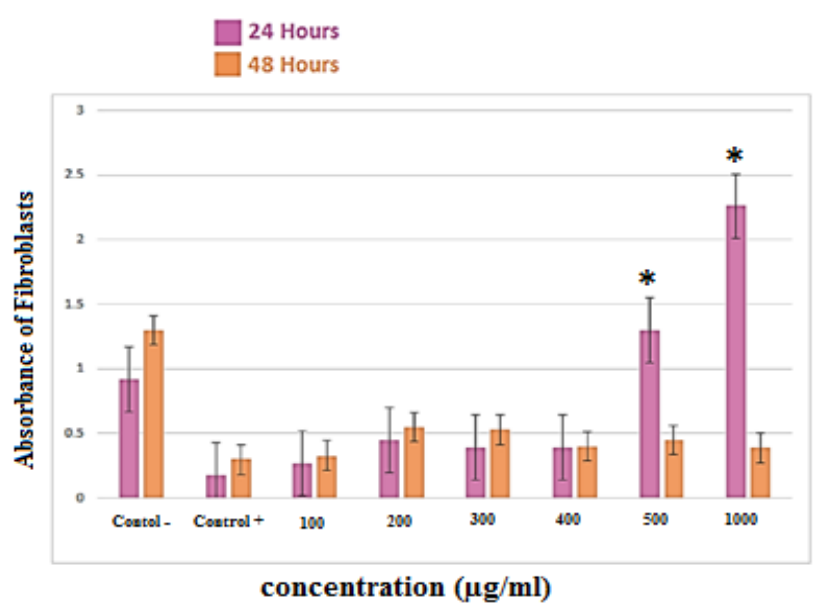

Figure 6: Anti-oxidant property of HeLa and NIH cells at different concentrations of mumie treated culture after 24 and $48 \mathrm{~h}$. *Significant difference $(\mathrm{P}<0.05)$ compared to the control culture

$\mathrm{H}_{2} \mathrm{O}_{2}$ assay of NIH cell mumie treated culture after $24 \mathrm{~h}$ revealed anti-oxidant property of high concentrations (500 and $1000 \mu \mathrm{g} / \mathrm{ml}$ ) of this natural material. The $\mathrm{NIH}$ cell viability increased 7 and 12 folds in concentration of 500 and 1000 $\mu \mathrm{g} / \mathrm{ml}$ mumie treated culture respectively when they compared to positive control culture but there is no anti-oxidant property in $48 \mathrm{~h}$ culture (Fig. 6).

\section{Discussion}

The cell proliferation measurement using MTT assay revealed mumie decreased HeLa cell viability even in low concentration and short time (24h) significantly (Figure 1). There was a 19, 31, 38, 43, 48 and $68 \%(p<0.05)$ reduction in the cell proliferation when the cells were incubated with 100 , $200,300,400,500$ and $1000 \mu \mathrm{g} / \mathrm{ml}$ concentration of mumie after $24 \mathrm{~h}$ respectively. The mumie treated culture after $48 \mathrm{~h}$ showed $35,45,65$ and $92 \%$ reduction in cell viability in 300 , 400,500 and $1000 \mu \mathrm{g} / \mathrm{ml}$ concentration of mumie after $48 \mathrm{~h}$ respectively. Mumie is not significant effects on NIH cell viability in similar condition to HeLa cells except in higher concentration of $1000 \mu \mathrm{g} / \mathrm{ml}$ mumie treated culture in both 24 and $48 \mathrm{~h}$ that revealed 49 and $70 \%$ reduction in viability respectively (Figure 1). MTT is a NADPH-dependent cellular oxidoreductase enzyme assay. It resulted insoluble purple color formazan, which represents the numbers of the viable cells (12). MTT assay indicates mumie anti-proliferative property in HeLa cells.

Mumie is a natural compound that mostly contains of humic substances. Many people around the world have used Mumie (shilajit) as a treatment for a variety of ailments. Different doses of shilajit from 200 to $1000 \mathrm{mg} / \mathrm{kg}$ on rats showed it has no side effects on vital organs including heart, liver, and kidneys (13). Many studies have suggested that mumie have immunomodulatory and anti-inflammatory activity. These examinations recommend that the lytic potential of polymorphonuclear leukocytes could be improved by shilajit. Mumie contains fulvic acid and humic acid, which are responsible for its biochemical activities. Humic matter has been reported to be anti-cancer agent as it inhibited the cancer cell growth and induced the apoptosis (14). The cytotoxic properties of humic acid was accompanied the ROS production (15) and NO synthesis (16).

Fulvic acid can increase extracellular anti-cancer mediators from RAW 264.7 cells that caused MCA-102 fibrosarcoma cells apoptosis. It also induced NF-KB activity which modulated the expression of NO and iNOS (17). Fulvic acid is an effective substance for inhibiting proliferation in cancer cells such as Hep3B, HT29 and PC3. It upregulates the mRNA levels of apoptotic genes of PC3 cells (18). Large population of HeLa cells showed either condensed chromatin after aniline blue staining or apoptotic signs after Ao/Eb staining (Figures 1-4). Mumie has induced chromatin condensation and apoptosis in all concentration of HeLa treated culture in both 24 and $48 \mathrm{~h}$. Apoptosis and chromatin condensation was increased with increasing concentrations of mumie. Chromatin condensation referred to compaction and hyperchromic nuclei of HeLa cells before they died. During cell death, chromatin undergoes the changes from a heterogeneous, genetically active network to an inert, highly condensed form. According to our results, different condensation of mumie did not show any side effects on NIH nuclei except for the highest dose of $1000 \mu \mathrm{g} / \mathrm{ml}$ concentration that proved toxic, leaving the highest possible number of cells dead. Humic acid (the major component of mumie) induced apoptosis in human premyelocytic leukemia HL-60 cells and showed loss of cell viability, chromatin condensation, and internucleosomal DNA fragmentation of these cells. Furthermore, caspase- 3 and the specific proteolytic cleavage of poly (ADP-ribose) polymerase activated, and Bax protein levels increased while Bcl-2 reduced (14). (19) has been reported cytotoxic effects of humic acid on human breast cancer cells.

polyphenols can repress the tumor generation and inhibit cancer cells growth. Tea decreases the danger of breast cancer (20). consumption of green tea and tomato resulted in reduction of prostate cancer in mouse models (21) (22). Our results revealed antioxidant activity of mumie on NIH cells. Mitochondria efficiency in generating ATP decrease in animals and in humans is associated with aging and oxidative stress. (23)treated mice with $20 \mathrm{mg}$ of a mixture of the 3hydroxydibenzo- $\alpha$-pyrone (3- OH-DBP) and 3,8dihydroxydibenzo- $\alpha$-pyrone $[3,8-(\mathrm{OH}) 2-\mathrm{DBP}$ isolated from shilajit. They revealed shilajit DBPs and their redox products upholds creation of ATP by hepatic mitochondria ((23)2009). Free radical scavenging activity of shilajit by 2,2-Diphenyl-1picrylhydrazyl (DPPH) assay has been reported (Rege et al., 2012). The effect of shilajit against some biogenic free radicals including $\left(\mathrm{O}_{2}{ }^{-*}\right),(\cdot \mathrm{OH})$, and $(\mathrm{NO})$ revealed it provided complete protection to methyl methacrylate (MMA) against hydroxyl radical-induced polymerization and acted as a reversible NO-captodative agent (24).

\section{Conclusion}

Mumie vastly used in southern Iran for a number of health complaints. In our study, Mumie had shown as potential antiproliferative and apoptotic properties. The evidence from the present study suggests that Mumie may be a factor in diet that may lower the risk of cancer and may inhibit the tumor growth and proliferation, apoptosis and oxidative stress.

\section{Ethical issue}

Authors are aware of, and comply with, best practice in publication ethics specifically with regard to authorship (avoidance of guest authorship), dual submission, manipulation of figures, competing interests and compliance with policies on research ethics. Authors adhere to publication requirements that submitted work is original and has not been published elsewhere in any language.

\section{Competing interests}

The authors declare that there is no conflict of interest that would prejudice the impartiality of this scientific work. 


\section{Authors' contribution}

All authors of this study have a complete contribution for data collection, data analyses and manuscript writing.

\section{References}

1. Ferlay J, Colombet M, Soerjomataram I, Mathers C, Parkin D, Piñeros $\mathrm{M}$, et al. Estimating the global cancer incidence and mortality in 2018: GLOBOCAN sources and methods. International journal of cancer. 2019;144(8):1941-53

2. Coates A, Abraham S, Kaye SB, Sowerbutts T, Frewin C, Fox R, et al. On the receiving end-patient perception of the side-effects of cancer chemotherapy. European Journal of Cancer and Clinical Oncology. 1983;19(2):203-8.

3. Waggoner SE. Cervical cancer. The Lancet. 2003;361(9376):2217-25

4. Safarzadeh E, Shotorbani SS, Baradaran B. Herbal medicine as inducers of apoptosis in cancer treatment. Advanced pharmaceutical bulletin. 2014;4(Suppl 1):421.

5. Ling C-q, Wang L-n, Wang Y, Zhang Y-h, Yin Z-f, Wang M, et al. The roles of traditional Chinese medicine in gene therapy. Journal of integrative medicine. 2014;12(2):67-75.

6. Ling C-q, Yue X-q, Ling C. Three advantages of using traditional Chinese medicine to prevent and treat tumor. Journal of integrative medicine. 2014;12(4):331-5.

7. Agarwal SP, Khanna R, Karmarkar R, Anwer MK, Khar RK. Shilajit: a review. Phytotherapy Research: An International Journal Devoted to Pharmacological and Toxicological Evaluation of Natural Product Derivatives. 2007;21(5):401-5.

8. Carrasco-Gallardo C, Guzmán L, Maccioni RB. Shilajit: a natural phytocomplex with potential procognitive activity. International Journal of Alzheimer's disease. 2012;2012.

9. Wilson E, Rajamanickam GV, Dubey GP, Klose P, Musial F, Saha FJ, et al. Review on shilajit used in traditional Indian medicine. J Ethnopharmacol. 2011;136(1):1-9.

10. Ghosal S, Baumik S, Chattopadhyay S. Shilajit induced morphometric and functional changes in mouse peritoneal macrophages. Phytotherapy Research. 1995;9(3):194-8.

11. Goel R, Banerjee R, Acharya S. Antiulcerogenic and antiinflammatory studies with shilajit. Journal of Ethnopharmacology. 1990;29(1):95-103.

12. Berridge MV, Herst PM, Tan AS. Tetrazolium dyes as tools in cell biology: new insights into their cellular reduction. Biotechnol Annu Rev. 2005; 11:127-52.

13. Anisimov V, Shakirzyanova R. Application of Mumie in therapeutic practice. Kazan Med Zh. 1982;63:65-8.

14. Yang H-L, Hseu Y-C, Hseu Y-T, Lu F-J, Lin E, Lai J-S. Humic acid induces apoptosis in human premyelocytic leukemia HL-60 cells. Life sciences. 2004;75(15):1817-31.

15. Ting H-C, Yen C-C, Chen W-K, Chang W-H, Chou M-C, Lu F-J. Humic acid enhances the cytotoxic effects of arsenic trioxide on human cervical cancer cells. Environ Toxicol Pharmacol. 2010;29(2):117-25

16. Hseu Y-C, Chang W-C, Hseu Y-T, Lee C-Y, Yech Y-J, Chen P$\mathrm{C}$, et al. Protection of oxidative damage by aqueous extract from Antrodia camphorata mycelia in normal human erythrocytes. Life Sci. 2002;71(4):469-82.

17. Jayasooriya RGPT, Dilshara MG, Kang C-H, Lee S, Choi YH, Jeong YK, et al. Fulvic acid promotes extracellular anti-cancer mediators from RAW 264.7 cells, causing to cancer cell death in vitro. International Immunopharmacology. 2016;36:241-8.

18. Aydin SK, Dalgic S, Karaman M, Kirlangic OF, Yildirim H Effects of fulvic acid on different cancer cell lines. Multidisciplinary Digital Publishing Institute Proceedings. 2017;1(10):1031.

19. Aykac A, Becer E, Okcanoğlu TB, Güvenir M, Süer K, Vatansever $\mathrm{S}$, editors. The cytotoxic effects of humic acid on human breast cancer cells. Multidisciplinary digital publishing institute proceedings; 2018.

20. Sun C-L, Yuan J-M, Koh W-P, Yu MC. Green tea, black tea and breast cancer risk: a meta-analysis of epidemiological studies. Carcinogenesis. 2006;27(7):1310-5.

21. Gupta S, Hastak K, Ahmad N, Lewin JS, Mukhtar H. Inhibition of prostate carcinogenesis in TRAMP mice by oral infusion of green tea polyphenols. Proceedings of the National Academy of Sciences. 2001;98(18):10350-5.

22. Limpens J, van Weerden WM, Krämer K, Pallapies D Obermüller-Jevic UC, Schröder FH. Re: Prostate Carcinogenesis in N-methyl-N-nitrosourea (NMU)-Testosterone-Treated Rat Fed Tomato Powder, Lycopene, or Energy-Restricted Diets. Journal of the National Cancer Institute. 2004;96(7):554-

23. Bhattacharyya S, Pal D, Banerjee D. Shilajit dibenzo-pyrones: Mitochondria targeted antioxidants. Pharmacologyonline. 2009;2:690-8.

24. Bhattacharya SK, Sen AP, Ghosal S. Effects of shilajit on biogenic free radicals. Phytotherapy Research. 1995;9(1):56-9. 